\title{
MOLECULAR CHARACTERIZATION OF VANCOMYCIN-RESISTANT Enterococci STRAINS EIGHT YEARS APART FROM ITS FIRST ISOLATION IN SÃO PAULO, BRAZIL
}

\begin{abstract}
SUMMARY
E. faecium was the first reported VRE species, carrying the vanA gene in Brazil. In spite of this, vancomycin-resistant $E$. faecalis has become the predominant species in Brazilian hospitals. The aim of this study was to evaluate the genetic relatedness of VREs isolated in a Brazilian teaching hospital eight years apart from its first isolation. We analyzed 38 VRE strains obtained from 81 surveillance cultures of patients admitted to the four largest intensive care units in Hospital São Paulo in February, 2006. Presence of the vanA gene was assayed by PCR and PFGE analysis was used for molecular characterization. All VRE strains carried the vanA gene. Two distinct clonal groups were observed among vancomycin-resistant E. faecalis. Vancomycin-resistant E. faecium belonged to five distinct clones were demonstrated by molecular typing. All of these clones were different from the first vancomycin-resistant enterococci clone isolated eight years ago in our hospital.
\end{abstract}

KEYWORDS: VRE; E. faecalis; E. faecium; PFGE ("Pulsed-Field Gel Electrophoresis").

\section{INTRODUCTION}

Enterococci became an important nosocomial pathogen due to their increasing role as opportunistic agents and their special ability to acquire resistance to antimicrobial drugs, including vancomycin ${ }^{18}$. Vancomycin-resistant enterococci (VRE) are a common cause of nosocomial infections and are important agents of gastrointestinal colonization. As the prevalence of VRE in hospitalized patients continues to increase, implementation of appropriate infection control measures requires routine surveillance of VRE transmission patterns ${ }^{19}$.

The first cases of human infections associated with VRE were detected in the late 1980s in Europe ${ }^{16}$ and in the United States ${ }^{15}$. Since then, VRE isolation has been reported from different parts of the world ${ }^{4}$ and surveillance programs for early VRE detection are currently recommended in order to prevent VRE spreading ${ }^{19}$. Vancomycinresistant enterococci have been an emerging problem in some Brazilian hospitals since the late 1990s. The first report of a VRE infection in Brazil occurred in 1996, in Curitiba ${ }^{10}$. Since 1997, the occurrence of VRE outbreaks has been documented in hospitals from other Brazilian cities $^{1,8,9,12,13,22,25,26}$. Vancomycin-resistant enterococci have been isolated in Hospital São Paulo (HSP) since 1998. Since then, a surveillance program has been carried out by the Infection Control Committee in order to identify patients harboring VRE and to implement contact precautions. Despite this intervention, vancomycin-resistant Enterococcus faecalis has became endemic in our setting thereafter.
On the other hand, studies on the clonality of vancomycin-resistant enterococci (VRE) are still limited in Brazil, mainly due to territory dimension, the differences in the population characteristics, and the number of nosocomial institutions over the country. The aim of this study was to determine the phenotypic and genotypic characteristics of VRE isolates eight years apart from its first isolation in our setting.

\section{MATERIALS AND METHODS}

Hospital São Paulo is a 750-bed university-affiliated hospital with an average of 177,000 patient-days per year. It comprises nine intensive care units (ICUs) and 41 medical and surgical wards. Since 1998, the Infection Control Committee has recorded the VRE incidence rate throughout the hospital. Surveillance through active rectal swab has been performed weekly in the four ICUs (Medical-Surgical, Medical, Pneumonology and Emergency) that have maintained higher rates of VRE incidence in the hospital. This incidence has varied from 17.4 isolates per 1,000 patient-days at Medical-Surgical ICU to 50.3 isolates per 1,000 patient-days at Emergency ICU. A total of 81 rectal swabs (one for each patient) obtained from patients admitted to those ICUs in February 2006 were examined. Only patients admitted for more than 48 hours were eligible for the study. All the rectal swabs were collected by the infection control team. Fecal samples were inoculated onto $\mathrm{NaCl} 0.9 \%$ and, after one hour, they were cultivated in VREBAC medium (PROBAC, Brazil) and incubated at $35{ }^{\circ} \mathrm{C}$ for $18-24$ hours. Suspected VRE colonies were submitted to identification using conventional biochemical tests and antimicrobial susceptibility ${ }^{11}$.

Part of this paper was presented at the $107^{\text {th }}$ General Meeting of the American Society for Microbiology (Toronto, Can, 2007).

Financial support: CNPq, FFFCMPA, LEMC.

(1)Laboratório Especial de Microbiologia Clínica (LEMC) da Universidade Federal de São Paulo (UNIFESP), São Paulo, SP, Brasil.

(2)Departamento de Microbiologia e Parasitologia da Fundação Faculdade Federal de Porto Alegre (FFFCMPA), Porto Alegre, RS, Brasil.

(3)Comissão de Epidemiologia Hospitalar, Hospital São Paulo, UNIFESP, São Paulo, SP, Brasil.

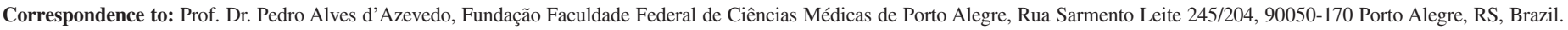

Phone/Fax 5551 33039000. E-mail: pedro_dazevedo@yahoo.com.br 


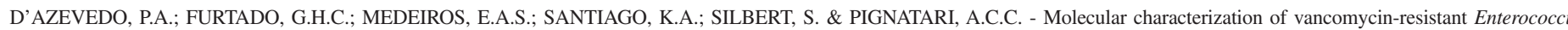
strains eight years apart from its first isolation in São Paulo, Brazil. Rev. Inst. Med. trop. S. Paulo, 50(4): 195-198, 2008.

Susceptibility to five antimicrobials (ampicillin, high-level gentamicin, high-level streptomycin, teicoplanin, and vancomycin) was evaluated by disk diffusion test, according to the Clinical Laboratory Standards Institute (CLSI) ${ }^{7}$. Minimum inhibitory concentrations (MICs) of ampicillin, gentamicin, streptomycin, teicoplanin and vancomycin were also determined by the gradient diffusion test (E test; AB Biodisk, Solna, Sweden) and by the agar-dilution method according to the CLSI guidelines ${ }^{7}$, in those isolates that presented resistance.

Detection of vancomycin-resistance genes was performed by polymerase chain reaction (PCR), using methods previously described ${ }^{6}$. The genetic relatedness of bacterial strains was evaluated by PFGE. Briefly, bacterial DNA was digested with SmaI and the restriction fragments were separated by electrophoresis on the CHEF DR III apparatus (BioRad, Hercules, CA). Running parameters were as follows: $200 \mathrm{~V}(6 \mathrm{~V} / \mathrm{cm})$; temperature, $13{ }^{\circ} \mathrm{C}$; initial switch time 5' and final 60' for $23 \mathrm{~h}$. After the electrophoresis run was completed, the PFGE gel was stained in a $0.08 \mu \mathrm{g} / \mathrm{mL}$ ethidium bromide solution. Macrorestriction patterns were determined by visual inspection. The isolates were classified as identical if they shared the same band profile, and different when differing by seven or more bands ${ }^{23}$. Three reference VRE strains were used to compare profiles in this study (first E. faecalis from HSP, first E. faecium from HSP and first E. faecalis from Porto Alegre).

\section{RESULTS}

Vancomycin-resistant isolates were detected in 37 (45.7\%) out of 81 fecal cultures. Vancomycin-resistant E. faecium was detected in 20 (54.1\%) out of these 37 patients and vancomycin-resistant. E. faecalis in $17(45.9 \%)$ out of these 37 patients. The proportion of colonized patients in ICUs was: Pneumonology - 41.6\%; Medical-Surgical - 14.2\%; Emergency $-15.3 \%$ and Medical - 40\%. Two different VRE species were detected in one patient (E. faecalis and E. faecium). The species isolates were identified and had their antimicrobial susceptibilities determined. The strains presented MICs of $1024 \mu \mathrm{g} / \mathrm{mL}$ and $256 \mu \mathrm{g} / \mathrm{mL}$ for vancomycin and teicoplanin respectively, and they all harbored the vanA gene. The MICs for gentamicin and streptomycin in E. faecalis were variable. $41.2 \%$ (7/17) and 29.4\% (5/17) were gentamicin-resistant and streptomycin-resistant respectively. In E. faecium, gentamicin resistance and streptomycin-resistance were $15.0 \%$ (3/20) and $90.0 \%$ (18/20), respectively. None E. faecalis strain was resistant to ampicillin whereas $95.0 \%$ (19/20) of E. faecium strains were ampicillin-resistant. With regard to the phenotypic similarity of species isolates, only two isolates per intensive care unit were randomly selected to be analyzed by PFGE (Tables 1 and 2). PFGE revealed the presence of two distinct vancomycin-resistant $E$. faecalis clones (Fig. 1) and five distinct $E$. faecium clones (Fig. 2). Among E. faecium, one of these clones were

Table 1

Results of nine vancomycin-resistant $E$. faecalis typed by PFGE

\begin{tabular}{|c|c|c|c|c|}
\hline Number & DD AMP/VANCO ${ }^{1}$ & E-test vancomycin/teicoplanin $\mu \mathrm{g} / \mathrm{mL}$ & $\mathrm{ICU}^{2}$ & Profile of PFGE \\
\hline 1 & $\mathrm{~S} / \mathrm{R}$ & $1024 / 256$ & Medical-surgical & “A” \\
\hline 2 & $\mathrm{~S} / \mathrm{R}$ & $1024 / 256$ & Medical-surgical & “A” \\
\hline 3 & $\mathrm{~S} / \mathrm{R}$ & $1024 / 256$ & Medical-surgical & "B" \\
\hline 4 & $\mathrm{~S} / \mathrm{R}$ & $1024 / 256$ & Emergency & "B" \\
\hline 5 & $\mathrm{~S} / \mathrm{R}$ & $1024 / 256$ & Emergency & "B" \\
\hline 6 & $\mathrm{~S} / \mathrm{R}$ & $1024 / 256$ & Emergency & "B" \\
\hline 7 & $\mathrm{~S} / \mathrm{R}$ & $1024 / 256$ & Medical & "B" \\
\hline 8 & $\mathrm{~S} / \mathrm{R}$ & $1024 / 256$ & Medical & "B” \\
\hline 9 & $\mathrm{R} / \mathrm{R}$ & $1024 / 256$ & First E. faecalis from HSP & "C" \\
\hline
\end{tabular}

${ }^{1}$ DD AMP/VANCO: disc diffusion test for ampicillin $(10 \mu \mathrm{g})$ and vancomycin $(30 \mu \mathrm{g})$; S: susceptible; R: resistant; ${ }^{2}$ intensive care units.

Table 2

Results of ten vancomycin-resistant $E$. faecium typed by PFGE

\begin{tabular}{|c|c|c|c|c|}
\hline Number & DD AMP/VANCO ${ }^{1}$ & E-test vancomycin/teicoplanin $\mu \mathrm{g} / \mathrm{mL}$ & $\mathrm{ICU}^{2}$ & Profile of PFGE \\
\hline 1 & $\mathrm{R} / \mathrm{R}$ & $1024 / 256$ & Pneumonology & "A" \\
\hline 2 & $\mathrm{~S} / \mathrm{R}$ & $1024 / 256$ & Medical-surgical & "B" \\
\hline 3 & $\mathrm{R} / \mathrm{R}$ & $1024 / 256$ & Medical-surgical & "C1" \\
\hline 4 & $\mathrm{R} / \mathrm{R}$ & $1024 / 256$ & Medical-surgical & “D” \\
\hline 5 & $\mathrm{R} / \mathrm{R}$ & $1024 / 256$ & Emergency & "C2" \\
\hline 6 & $\mathrm{R} / \mathrm{R}$ & $1024 / 256$ & Medical & "B" \\
\hline 7 & $\mathrm{R} / \mathrm{R}$ & $1024 / 256$ & Pneumonology & "B" \\
\hline 8 & $\mathrm{R} / \mathrm{R}$ & $1024 / 256$ & Emergency & "B" \\
\hline 9 & $\mathrm{R} / \mathrm{R}$ & $1024 / 256$ & Medical & "E" \\
\hline 10 & $\mathrm{R} / \mathrm{R}$ & $1024 / 256$ & First E. faecium from HSP & "F" \\
\hline
\end{tabular}

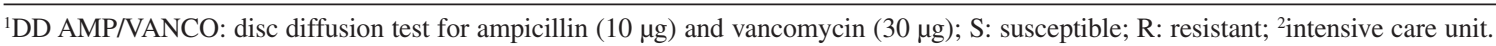




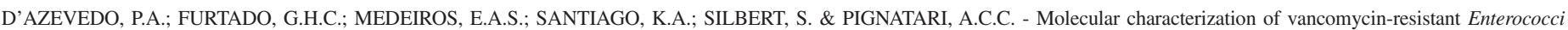
strains eight years apart from its first isolation in São Paulo, Brazil. Rev. Inst. Med. trop. S. Paulo, 50(4): 195-198, 2008.

identified in four isolates from four different patients; each one from a different ICU. All of these clones were different from the first VRE clones detected eight years ago in our hospital.

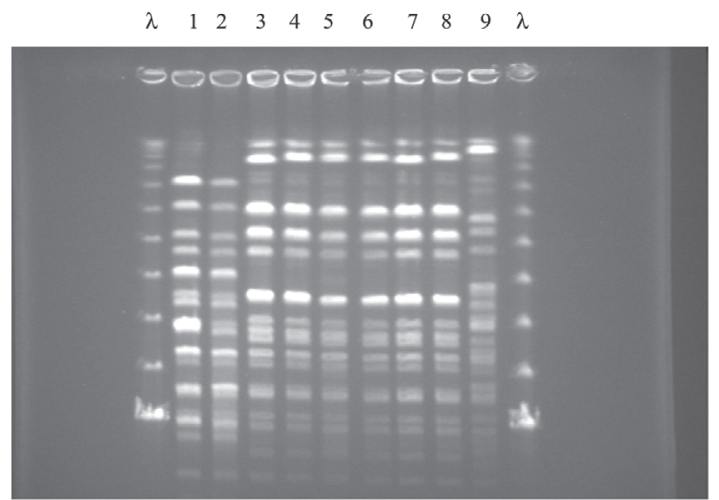

Fig. 1 - PFGE profiles of SmaI-digested chromosomal DNA of vancomycin-resistant $E$. faecalis isolates obtained from colonized inpatients from Hospital São Paulo, Brazil. Lanes 1, molecular size markers (48.5kb). lane 1: clone "A"; lane 2: clone "A"; lanes 3-8: clone "B"; lane 9: clone "C".

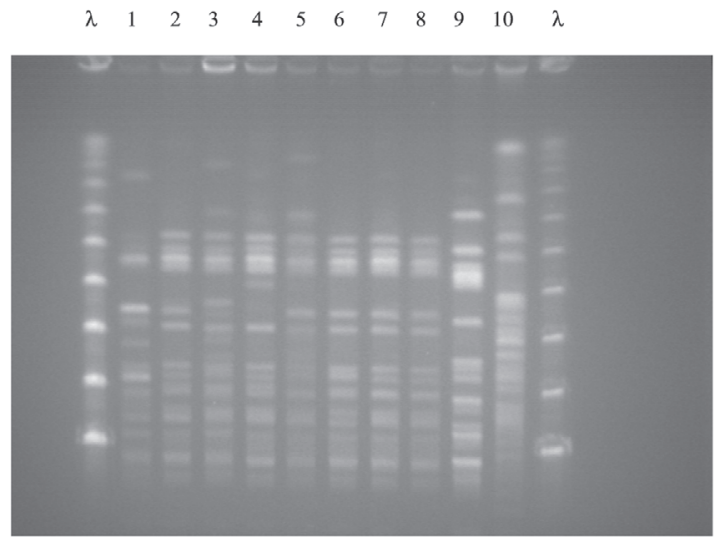

Fig. 2 - PFGE profiles of SmaI-digested chromosomal DNA of vancomycin-resistant $E$. faecium isolates obtained from patients from Hospital São Paulo, Brazil. 1: lambda ladder (48.5 kb); lane 1: clone "A"; lane 2: clone "B"; lane 3: clone "C1"; lane 4: clone "D"; lane 5: clone "C2"; lane 6: clone "B"; lane 7: clone "B"; lane 8: clone "B"; lane 9: clone "E"; lane 10: clone "F".

\section{DISCUSSION}

Glycopeptide resistance is disseminated among E. faecium isolates around the world ${ }^{14}$. However, to date the first reported VRE outbreaks were attributed to E. faecalis ${ }^{1,3,8,12,13,22}$, while occurrence of vancomycinresistant $E$. faecium has been sporadic ${ }^{10,25}$. On the other hand, the first VRE isolated in Brazil was an E. faecium strain with the vanD2 phenotype recovered from a patient with sepsis in Curitiba. This fact drew attention for a potential problem that might be coming along in our healthcare institutions thereafter ${ }^{10}$. In the following years, no additional cases of VRE were detected in Curitiba, although several cases of VRE identified as either E. faecium or E. faecalis harboring VanA phenotype were documented in São Paulo ${ }^{25,26}$.

VRE became increasingly problematic for institutions in which they now are endemic. Controlling the VRE spreading may become a less difficult and costly task if the epidemiology is better understood ${ }^{21}$. In these settings, colonized and infected patients and colonized environmental surfaces may serve as persistent reservoirs. The molecular epidemiology of VRE in a setting where it is endemic is more complex. Several patterns of VRE transmission in non-outbreak periods have been reported (eg. polyclonal, oligoclonal, monoclonal) $)^{2,5,17,20,21,24}$. Molecular-typing techniques can be important tools for efficiently identifying clonal VRE dissemination. The heterogeneity of nosocomial VRE in centers in which this organism is endemic likely reflects antimicrobial selective pressure at work in highrisk patient populations combined with the constant introduction of new strains by patients transferred from other institutions ${ }^{21}$.

In our institution, eight years apart from its introduction, vancomycin-resistant $E$. faecalis has remained apparently oligoclonal in the ICUs. On the other hand, we have noted a regular appearance of E. faecium over the last years with its worse resistance profile. The widespread dissemination of these two species likely reflects the transfer of patients with undetected colonization between hospital wards. However, the reasons for the maintenance of this oligoclonal pattern in our institution are unclear. Vancomycin-resistant E. faecalis incidence has been maintained high but stable in the last three years in our setting. Thus, the infection control measures must be reinforced in order to reduce these high incidence rates.

All vancomycin-resistant $E$. faecalis clones identified in this study were distinct from the first one previously isolated in HSP. In addition, the major vancomycin-resistant $E$. faecalis clone isolated in our setting is similar to those previously isolated in Porto Alegre and Rio de Janeiro in $2001^{22}$. The predominant clone, denominated "B" has high-level of resistance to gentamicin and was isolated from three ICUs. This fact may suggest an inter-hospital dissemination of this clone among Brazilian states.

Faster VRE detection methods may control the nosocomial spread of this pathogen among new patients that may become index cases for dissemination ${ }^{21}$. In our study we used the PCR method, which provide results in less than 48 hours and proved to be an excellent method to identify this microorganism.

In conclusion, the present study demonstrated that the initial VRE clones (mainly E. faecalis) were replaced by new ones, eight years apart from its first isolation in our hospital. Certainly, the spread of a single clone via patient-to-patient transmission through healthcare professional hands represents the major concern for infection control team. Probably, VRE will continue to be a significant nosocomial pathogen and continuous efforts aimed to understanding their molecular epidemiology are warranted.

\section{RESUMO}

\section{Caracterização molecular de espécies de Enterococci resistentes à vancomicina oito anos após seu primeiro isolamento em São Paulo, Brasil}

E. faecium contendo o gene vanA foi a primeira espécie de VRE descrita, no Brasil. Apesar disto, E. faecalis resistente a vancomicina 


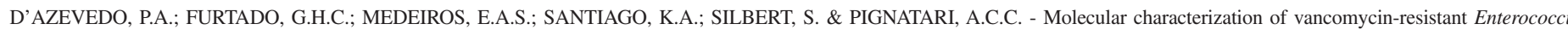
strains eight years apart from its first isolation in São Paulo, Brazil. Rev. Inst. Med. trop. S. Paulo, 50(4): 195-198, 2008.

tem se tornado a espécie predominante nos hospitais brasileiros.O objetivo desse estudo foi avaliar a relação genética de VREs isolados em um hospital de ensino brasileiro após oito anos de seu primeiro isolamento. Analisamos 37 isolados de VRE obtidos de 81 culturas de vigilância de pacientes admitidos nas quatro maiores Unidades de Tratamento Intensivo em Fevereiro de 2006. A presença do gene vanA foi analisada por PCR e a caracterização molecular por PFGE. Todas as amostras VRE carreavam o gene vanA. Entre os E. faecalis vancomicina-resistentes, dois distintos grupos clonais foram observados. E. faecium resistente a vancomicina pertencentes a cinco clones distintos foram demonstrados por tipagem molecular. Todos esses clones foram diferentes do primeiro clone de enterococo resistente a vancomicina isolado oito anos atrás em nosso hospital.

\section{ACKNOWLEDGMENTS}

This study was supported by Conselho Nacional de Desenvolvimento Científico e Tecnológico (CNPq), Fundação Faculdade Federal de Ciências Médicas de Porto Alegre (FFFCMPA), and Laboratório Especial de Microbiologia Clínica (LEMC), Universidade Federal de São Paulo (UNIFESP), Brazil.

\section{REFERENCES}

1. ALBUQUERQUE, V.S.; SILVA, C.M.F.; MARQUES, E.A.; TEIXEIRA, L.M. \& MERQUIOR, V.L.C. - Occurrence of vancomycin-resistant Enterococcus faecalis in Rio de Janeiro, Brazil: strains showed genetic relationship with high-level gentamicin resistant (HLGR) endemic clone. In: INTERSCIENCE CONFERENCE ON ANTIMICROBIAL AGENTS AND CHEMOTHERAPY, 40., Toronto, 2000. Abstracts. p. 107.

2. BONTEN, M.J.; HAYDEN, M.K.; NATHAN, C. et al. - Epidemiology of colonization of patients and environment with vancomycin-resistant enterococci. Lancet, 348 : $1615-1619,1996$

3. CAIAFFA FILHO, H.H.; ALMEIDA, G.D.; OLIVEIRA, G.A. et al. - Molecular characterization of van genes found in vancomycin-resistant Enterococcus spp. isolated from Hospital das Clínicas, FMUSP, São Paulo, Brazil. Braz. J. infect. Dis., 7: 173-174, 2003.

4. CETINKAYA, Y.; FALK, P. \& MAYHALL, C.G. - Vancomycin-resistant enterococci. Clin. Microbiol. Rev., 13: 686-707, 2000.

5. CHOW, J.W.; KURITZA, A.; SHLAES, D.M. et al. - Clonal spread of vancomycinresistant Enterococcus faecium between patients in three hospitals in two states. J. clin. Microbiol., 31: 1609-1611, 1993.

6. CLARK, N.C.; TEIXEIRA, L.M.; FACKLAM, R.R. \& TENOVER, F. - Detection and differentiation of vanC-1, vanC-2, and vanC-3 glycopeptide resistance genes in enterococci. J. clin. Microbiol., 36: 2294-2297, 1998.

7. CLINICAL AND LABORATORY STANDARDS INSTITUTE - Performance standards for antimicrobial susceptibility testing. Wayne, 2005. (15 ${ }^{\text {th }}$ Informational Supplement. CLSI Document M100-S15).

8. CORDEIRO, J.C.R.; SILBERT, S.; REIS, A.O. \& SADER, H.S. - Inter-hospital dissemination of glycopeptide-resistant Enterococcus faecalis in Brazil. Clin. infect. Dis., 10: 260-262, 2004

9. D’AZEVEDO, P.A.; KACMAN, S.B.; SCHMALFUSS, T.; SILVA, A. \& RODRIGUES, L.F. - Primeiro caso de Enterococcus resistente a vancomicina isolado em Porto Alegre, RS. J. bras. Pat., 36: 258, 2000.

10. DALLA-COSTA, L.M.; SOUZA, D.C.; MARTINS, L.T. et al. - Vancomycin-resistant Enterococcus faecium: first case in Brazil. Braz. J. infect. Dis., 2: 160-163, 1998.
11. FACKLAM, R.R.; SAHM, D.A. \& TEIXEIRA, L.M. - Enterococcus. In: MURRAY, P.R.; BARON, E.J.; PFALLER, M.A.; TENOVER, F.C. \& YOLKEN, R.H., ed. Manual of clinical Microbiology. Washington, American Society for Microbiology, 1999. p. 297-305.

12. FURTADO, G.H.; MARTINS, S.T.; COUTINHO, A.P.; WEY, S.B. \& MEDEIROS, E.A - Prevalence and factors associated with rectal vancomycin-resistant enterococci colonization in two intensive care units in São Paulo, Brazil. Braz. J. infect. Dis., 9: 64-69, 2005.

13. FURTADO, G.H.; MARTINS, S.T.; COUTINHO, A.P. et al. - Incidence of vancomycin resistant Enterococcus at a university hospital in Brazil. Rev. Saúde públ. (S. Paulo), 39: 41-46, 2005

14. HAYDEN, M.K. - Insights into the epidemiology and control of infection with vancomycin-resistant enterococci. Clin. infect. Dis., 31: 1058-1065, 2000.

15. KAPLAN, A.H.; GILLIGAN, P.H. \& FACKLAM, R.R. - Recovery of resistant enterococci during vancomycin prophylaxis. J. clin. Microbiol., 26: 1216-1218, 1988.

16. LEClERCQ, R.; DERLOT, E.; DUVAL, J. \& COURVAlin, P. - Plasmid mediated resistance to vancomycin and teicoplanin in Enterococcus faecium. New Engl. J. Med., 319: 157-161, 1988.

17. MORRIS, J.G.; SHAY, D.K.; HEBDEN, J.N. et al. - Enterococci resistant to multiple antimicrobial agents, including vancomycin. Establishment of endemicity in a university medical center. Ann. intern. Med., 123: 250-259, 1995.

18. MUNDY, L.M.; SAHM, D.F. \& GILMORE, M. - Relationships between enterococcal virulence and antimicrobial resistance. Clin. Microbiol. Rev., 13: 513-522, 2000.

19. MUTO, C.A.; JERNIGAN, J.A.; OSTROWSKY, B.E. et al. - SHEA guideline for preventing nosocomial transmission of multidrug-resistant strains of Staphylococcus aureus and Enterococcus. Infect. Control Hosp. Epidem., 24: 362-386, 2003.

20. OSTROWSKY, B.E.; VENKATARAMAN, L.; D'AGATA, E.M.C. et al.- Vancomycinresistant enterococci in intensive care units: high frequency of stool carriage during non-outbreak periods. Arch. intern. Med., 159: 1467-1472, 1999.

21. STOSOR, V.; KRUSZYNSKI, J.; SURIANO, T.; NOSKIN, G.A. \& PETERSON, L.R. Molecular epidemiology of vancomycin-resistant enterococci: a 2-year perspective. Infect. Control Hosp. Epidem., 20: 653-659, 1999.

22. TEIXEIRA, L.M.; D'AZEVEDO, P.A.; DIAS, C.G. et al. - Genetic relationship of vancomycin-resistant Enterococcus faecalis strains carrying the van A gene isolated in Porto Alegre city, Brazil. In: INTERSCIENCE CONFERENCE ON ANTIMICROBIAL AGENTS AND CHEMOTHERAPY, 41., Chicago, 2001. Program and abstracts. Washington, American Society for Microbiology, 2001. p. 126, Abstract C2-513.

23. TENOVER, F.C.; ARBEIT, R.D.; GEORING, R.V. et al. - Interpreting chromosomal DNA restriction patterns produced by pulsed-field gel electrophoresis: criteria for bacterial strain typing. J. clin. Microbiol., 33: 2233-2239, 1995.

24. TOKARS, J.I.; SATAKE, S.; RIMLAND, D. et al. - The prevalence of colonization with vancomycin-resistant Enterococcus at a Veterans Affairs institution. Infect. Control Hosp. Epidem., 20: 171-175, 1999.

25. ZANELLA, R.C.; VALDERATO, F.; LOVGREN, M. et al. - First confirmed case of a vancomycin-resistant Enterococcus faecium with VanA phenotype from Brazil: isolation from a meningitides case in São Paulo. Microb. Drug resist., 5: 159-162, 1999.

26. ZANELLA, R.C.; BRANDILEONE, M.C.; BOKERMANN, S. et al. - Phenotypic and genotypic characterization of VanA Enterococcus isolated during the first nosocomial outbreak in Brazil. Microb. Drug resist., 9: 283-291, 2003.

Received: 19 October 2007

Accepted: 30 June 2008 